\title{
Photosensitizers in prostate cancer therapy
}

\author{
Taher Gheewala ${ }^{1}$, Troy Skwor ${ }^{2}$ and Gnanasekar Munirathinam ${ }^{1}$ \\ ${ }^{1}$ Department of Biomedical Sciences, University of Illinois, College of Medicine, Rockford, IL, USA \\ 2 Department of Chemical and Biological Sciences, Rockford University, Rockford, IL, USA \\ Correspondence to: Gnanasekar Munirathinam, email: mgnanas@vic.edu \\ Keywords: prostate cancer, photodynamic therapy, photosensitizers \\ Received: October 29, $2016 \quad$ Accepted: February 06, $2017 \quad$ Published: February 18, 2017
}

Copyright: Gheewala et al. This is an open-access article distributed under the terms of the Creative Commons Attribution License (CC-BY), which permits unrestricted use, distribution, and reproduction in any medium, provided the original author and source are credited.

\section{ABSTRACT}

The search for new therapeutics for the treatment of prostate cancer is ongoing with a focus on the balance between the harms and benefits of treatment. New therapies are being constantly developed to offer treatments similar to radical therapies, with limited side effects. Photodynamic therapy (PDT) is a promising strategy in delivering focal treatment in primary as well as post radiotherapy prostate cancer. PDT involves activation of a photosensitizer (PS) by appropriate wavelength of light, generating transient levels of reactive oxygen species (ROS). Several photosensitizers have been developed with a focus on treating prostate cancer like mTHPC, motexafin lutetium, padoporfin and so on. This article will review newly developed photosensitizers under clinical trials for the treatment of prostate cancer, along with the potential advantages and disadvantages in delivering focal therapy.

\section{INTRODUCTION}

Prostate cancer $(\mathrm{PCa})$ is the second most common cancer in men. In 2016, the American Cancer Society has estimated 180,890 new cases of PCa in the United States alone resulting in 26,120 deaths [1]. Current treatment options, although effective, pose severe side effects that impact the quality of life of patients. As screening procedures have become more aggressive and accessible, it has aided in screening and diagnosis of early stage $\mathrm{PCa}$ [2]. Radical therapies available for organ confined cancer involve physical or chemical castration. Active surveillance, or delayed selective intervention for men with organ confined low risk $\mathrm{PCa}$, has given rise to an interest in focal therapy, which can be organ-sparing. Focal therapy is aimed at treating clinically relevant volumes of cancer within the gland while leaving other areas untreated. A number of modalities have been identified to deliver such treatment like high-intensity focused ultrasound [3], cryotherapy [4], and photodynamic therapy (PDT). The first use of PDT in a clinical setting for PCa used two tissue based photosensitizers (PS) in two patients, where one received a hematoporphyrin derivative and the other received Photofrin. The 3 month biopsy of these two patients showed neither had residual disease [5]. Another study assessed the uptake of ALA in PCa in six patients. Fluorescence microscopy showed ALA had been taken up in the cancer cells sparing the surrounding tissue [6]. However, prolonged skin photosensitivity and less tissue penetration of short wavelength light are common problems associated with first generation PS. The formation of aggregates of the PS inside of cells, leads to increased susceptibility to prolonged phototoxicity. This has led to the development of second and third generation PS, which are eliminated from the body within hours of administration. This review is aimed at discussing such photosensitizers that are in clinical trials for the treatment of PCa.

\section{PHOTODYNAMIC THERAPY}

Photodynamic therapy (PDT) is a minimally invasive and clinically approved therapy that can be used for early stage disease [7]. PDT involves 3 main components: a photosensitizer, light and tissue oxygen. The basic principle of PDT is that the photosensitizer is activated from its singlet ground state $\left(\mathrm{S}_{0}\right)$ to a short lived excited singlet state $\left(S_{1}\right)$ upon irradiation with light of appropriate wavelength. The $\mathrm{S}_{1}$ can return to $\mathrm{S}_{0}$ state by emitting the absorbed energy as fluorescence, or dissipation in the form of heat [8]. Alternatively, $\mathrm{S}_{1}$ can convert to a longer lived triplet state $\left(\mathrm{T}_{1}\right)$ via intersystem crossing. The energy transfer from $T_{1}$ to 
Table 1: Summary of characteristics of various photosensitizers

\begin{tabular}{|c|c|c|c|c|c|}
\hline Photosensitizer & $\begin{array}{c}\text { Mode of } \\
\text { action }\end{array}$ & $\begin{array}{c}\text { Activation } \\
\text { wavelength }\end{array}$ & $\begin{array}{c}\text { Route of } \\
\text { administration }\end{array}$ & Advantages & Disadvantages \\
\hline $\begin{array}{l}\text { Porfimer sodium } \\
\text { (Photofrin) }\end{array}$ & $\begin{array}{l}\text { Tissue } \\
\text { based }\end{array}$ & $405 \mathrm{~nm}$ & Intravenous & $\begin{array}{c}\text { Preparation less } \\
\text { heterogenous than HpD } \\
\text { derivatives }\end{array}$ & $\begin{array}{c}\text { Prolonged skin } \\
\text { photosensitivity; long drug- } \\
\text { light intervals; suboptimal } \\
\text { tumor selectivity }\end{array}$ \\
\hline $\begin{array}{l}\text { Aminolevulinic acid } \\
\text { (5-ALA) }\end{array}$ & $\begin{array}{l}\text { Tissue } \\
\text { based }\end{array}$ & $410 \mathrm{~nm}$ & Oral or topical & $\begin{array}{l}\text { Selectivity for cancer } \\
\text { cells; short drug light } \\
\text { interval (up to } 4 \text { hours) }\end{array}$ & Less tissue penetration \\
\hline Verteporfin & $\begin{array}{l}\text { Tissue } \\
\text { based }\end{array}$ & $692 \mathrm{~nm}$ & Intravenous & $\begin{array}{l}\text { Selectivity for cancer } \\
\text { cells; short drug light } \\
\text { interval (15-30 mins) }\end{array}$ & Visual disturbances reported \\
\hline mTHPC (Foscan) & $\begin{array}{l}\text { Tissue } \\
\text { based }\end{array}$ & $652 \mathrm{~nm}$ & Intravenous & Low dose required & $\begin{array}{c}\text { Prolonged skin } \\
\text { photosensitivity (upto } 6 \\
\text { weeks); drug light interval } \\
\text { of 3-5 days }\end{array}$ \\
\hline $\begin{array}{l}\text { Motexafin lutetium } \\
\text { (MLu) }\end{array}$ & $\begin{array}{l}\text { Vascular } \\
\text { acting }\end{array}$ & $732 \mathrm{~nm}$ & Intravenous & $\begin{array}{l}\text { Short drug - light } \\
\text { interval ( } 3 \text { hours); } \\
\text { no reported skin } \\
\text { photosensitivity }\end{array}$ & No disadvantage reported \\
\hline TOOKAD & $\begin{array}{l}\text { Vascular } \\
\text { acting }\end{array}$ & $763 \mathrm{~nm}$ & Intravenous & $\begin{array}{l}\text { Short drug-light interval } \\
\text { (mins); no reported skin } \\
\text { photosensitivity }\end{array}$ & No disadvantage reported \\
\hline
\end{tabular}

biological substrates or molecular oxygen generates reactive oxygen species (ROS) (Figure 1), causing cellular damage leading to death mainly by apoptosis or necrosis [9]. PDT has proven to exert selective cytotoxicity towards malignant cells, leading to cell death $[10,11]$. Several photosensitizers that have been studied include hematoporphyrin derivatives (Photofrin), aminolevulinic acid (5-ALA), verteporfin (visudyne), chlorophyll derivatives (pheophorbide a) and more. PDT is frequently used on cutaneous lesions, but has also been tested on cancers of breast [12], lung [13], head and neck [14], esophageal [15, 16], bladder [17] and prostate [18]. Table 1 summarizes the characteristics of different photosensitizers used in PDT, for the treatment of cancer.

\section{mTHPC}

Mesotetra (hydroxyphenyl) chlorin (mTHPC, Foscan) is a single pure chlorine compound, and one of the most potent second generation photosensitizers. Several clinical studies have shown that mTHPC is 100200 times more potent than Photofrin, which is the most widely used first generation photosensitizer. With an excitation wavelength at $652 \mathrm{~nm}$, it presents a high tumor selectivity. mTHPC is a highly hydrophobic molecule, and this nature ensures its localization in critical intracellular membranous organelles [19].

Several studies have formulated different conjugates of mTHPC to achieve maximal effect. The first commercial liposomal formulation of mTHPC was Foslip. This method involves encapsulating mTHPC in liposomes, which helps decrease the tendency of the photosensitizer to form aggregates thus improving solubility in aqueous media [20]. Petri et al. [21] optimized cellular uptake and photodynamic efficiency of mTHPC using a PEGylated liposomal formulation of mTHPC called Fospeg in PCa cell lines and compared its efficiency to Foscan. The results showed that the intracellular concentration of Fospeg was increased compared to Foscan, with neither demonstrating any dark cytotoxicity. Another group developed 'Theranosomes', which are precursor cells (Human macrophages derived from monocytic THP1 cell line), loaded with photosensitizer (mTHPC) and magnetic nanoparticles [22]. They assessed the delivery of mTHPC both in vitro (PC3 PCa cells) and in vivo (TC1 murine cervical cancer), followed by PDT treatment. A dose dependent uptake of theranosomes correlated with significant decrease in cell viability post-PDT in vitro and tumor size in mice.

The cell death pathways evoked by mTHPC mediated PDT involve oxidative damage which may lead to apoptosis, autophagy or necrosis. Lower doses of photosensitizer have reported apoptosis [23, 24] while higher doses usually lead to autophagy or necrosis [25]. It has been reported that upon PDT treatment there is an increase in ROS which can kill a portion of the cells immediately, while others undergo a death process which takes several hours. mTHPC - PDT was reported to induce immediate DNA damage and reduction of RNA due to ROS production in PC-3 cells. Also, reduced levels of genes involved in cellular defense mechanisms against oxidative and metabolic stress were observed. Furthermore, some HSP70 members were also down regulated [26]. mTHPC - PDT also blocks proliferation and induces cell cycle arrest [27]. 
As compared to hollow organs, the prostate is a solid organ which makes it challenging for PDT. Several studies have shown necrosis of glandular tissue in hollow organs with little effect on connective tissue. Healing of necrotic tissue in large volumes post PDT is much slower as compared to healing of mucosa in hollow organs [28]. Canine studies of PCa with mTHPC - PDT have shown glandular areas of hemorrhagic necrosis which healed with fibroblast infiltration, but there was still glandular atrophy post 90 days [29]. PDT of prostate can produce areas of rectal mucosal necrosis, however these areas heal with the regeneration of normal mucosa [29].

With its success as a potential therapeutic, mTHPC - PDT has found its way into clinical trials. A study performed at University College London Hospitals assessed mTHPC - PDT in early PCa [28]. The approach did not involve treatment of the whole gland, but only areas of cancer as detected by biopsy. One patient had a period of mild incontinence ( 4 months) which resolved spontaneously. Another patient experienced reduction in erectile function which was due to right and left neurovascular bundles in the PDT treated areas. A reduction in prostate volume was also observed, whereas PDT studies on normal canine prostate showed necrosis of glandular tissue with preservation of collagen with minimal changes in volume [30]. There was also a significant reduction in PSA levels in the human patients. Another study involved the combination of
mTHPC - PDT with fluoropyrinimides, which are used in chemotherapeutic treatment, on PCa cell lines [31]. 5-fluoro-2'-deoxyuridine (5FdUr) was used in this study due to different modes of action of both drugs. mTHPC being lipophilic, accumulates mainly in membranes excluding the nucleus, while 5FdUr acts in the cytosol by inhibiting thymidylate synthase and is incorporated in RNA and DNA [32]. The combination treatment showed higher concentrations of $5 \mathrm{FdUr}$ with $0.1 \mu \mathrm{M}$ mTHPC PDT has an antagonistic effect, while lower concentrations of 5FdUr has an additive effect, with more cell death in comparison to individual treatments.

\section{TOOKAD}

TOOKAD or WST09 (padoporfin) is a relatively new second generation photosensitizer drug, which is a pure palladium (Pd) - substituted bacteriochlorophyll derivative with a peak absorption wavelength at $763 \mathrm{~nm}$. TOOKAD acts by damaging vasculature and altering blood supply and is generally described as vascular targeted photodynamic therapy (VTP). Damage of vascular endothelium is followed by a series of events, like thrombosis, blood stasis, and vessel occlusion, ultimately leading to tumor necrosis (Figure 2) [33, 34]. It has a relatively fast clearance rate from the body. Several studies have investigated the potential of TOOKAD as a therapeutic to treat $\mathrm{PCa}$, mainly in patients who failed

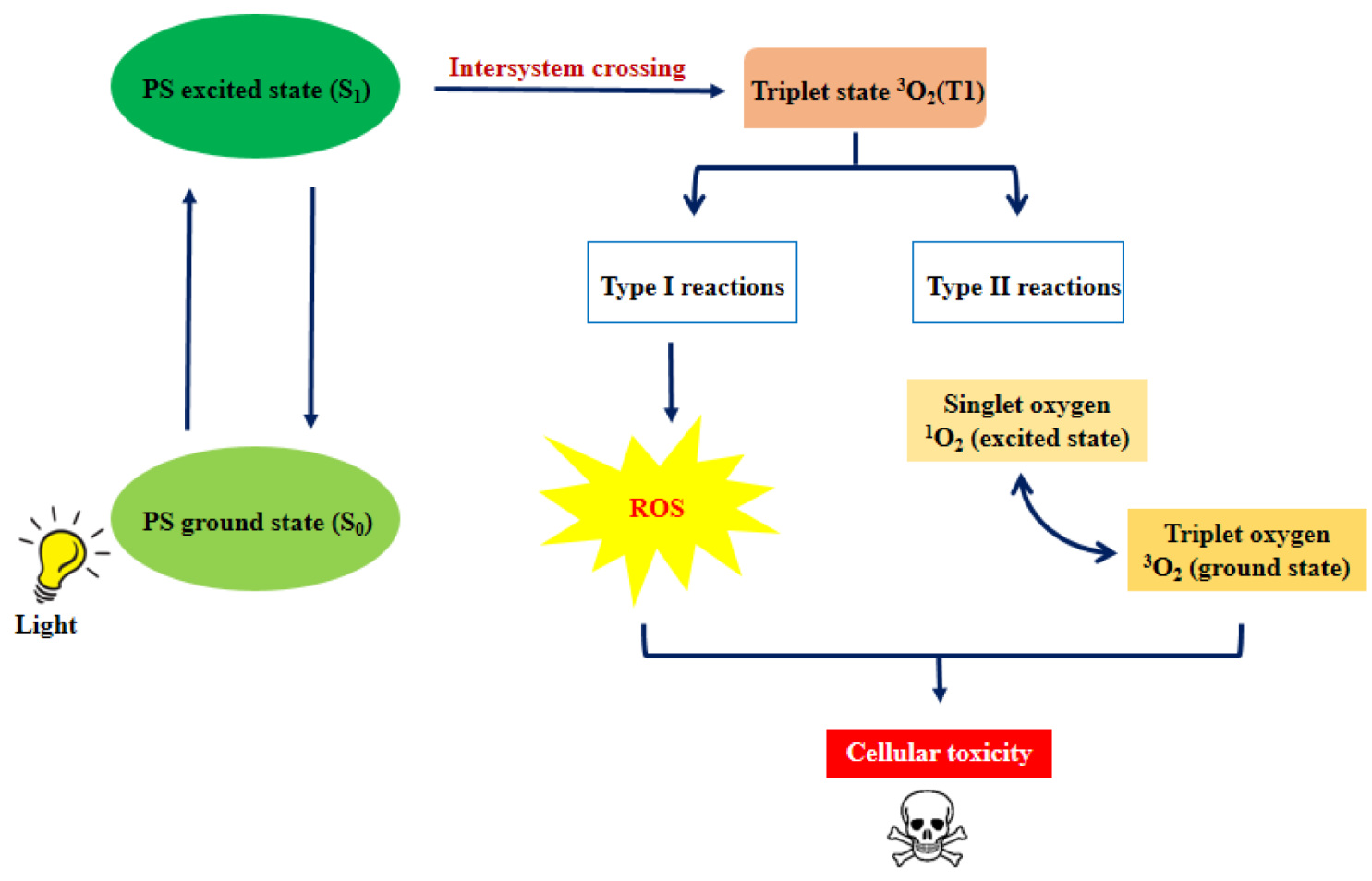

Figure 1: Mechanism of PDT. Upon light activation, the photosensitizer is excited $\left(\mathrm{S}_{0}\right.$ to $\left.\mathrm{S}_{1}\right) . \mathrm{S}_{1}$ is converted to a more stable triplet state via intersystem crossing. Further, type I reactions involve the formation of ROS, whereas, the loss of energy in type II reactions leads to the formation of highly reactive singlet oxygen species; ultimately leading to cellular toxicity. 
prior radiotherapy.

A phase I study to evaluate the safety of TOOKAD - VTP reported it to be safe with no serious adverse events [35]. A phase II trial was initiated by the same group enrolling 28 patients to study the effects of TOOKADVTP with escalating light doses [36]. Patients received a $2 \mathrm{mg} / \mathrm{kg}$ dose and light doses were specified by computeraided treatment planning [37]. The treatment response was assessed by measuring PSA levels, lesion formation (using MRI) and 6-month biopsy. Treatment of the whole prostate was achieved with minimal effects on surrounding organs. They also reported improved treatment efficacy with increased light dose for almost $80 \%$ of the prostate in some patients with a decrease in PSA levels. Severe cutaneous photosensitivity is a common problem with PDT drugs, but due to TOOKAD's fast clearance, this is greatly reduced. About $80 \%$ of TOOKAD was cleared from patients within 30 minutes, with negligible concentrations at 150 minutes [38].

The canine prostate has proved to be a good model due to its resemblance both in physical size and in anatomical structure to that of the human prostate. Canine prostate PDT with various photosensitizers has been investigated since the early 1980s [39, 40]. On investigating the effects of TOOKAD PDT on the prostate and surrounding tissues in canine model, hemorrhagic necrosis was observed at one week post TOOKAD PDT in the prostate and prostatic urethra. Mild inflammation was observed on the bladder, colon, abdominal muscle and pelvic plexus [41, 42]. The same group studied effects of TOOKAD-PDT on canine prostate pre-treated with ionizing radiation to produce physiological and anatomical relevance similar to patients for whom radiotherapy has failed. They reported TOOKAD-PDT can safely destroy prostate tissue that has previously received radiation therapy [43]. Another group studied the effects of TOOKAD PDT on peripheral nerve tissue in the saphenous nerve using an in situ canine model. It was demonstrated that TOOKAD PDT induced conductivity changes, which depended on both drug and light dose. Treatment with drug alone, light alone, or low dose PDT produced little to no change in nerve conduction properties. Lower light dose $\left(50 \mathrm{~J} / \mathrm{cm}^{2}\right)$ with a drug dose of $2 \mathrm{mg} / \mathrm{kg}$ caused little nerve tissue damage while higher light dose $\left(200 \mathrm{~J} / \mathrm{cm}^{2}\right)$ and a drug dose of $1 \mathrm{mg} / \mathrm{kg}$ caused marked damage to the nerve and surrounding tissue [44].

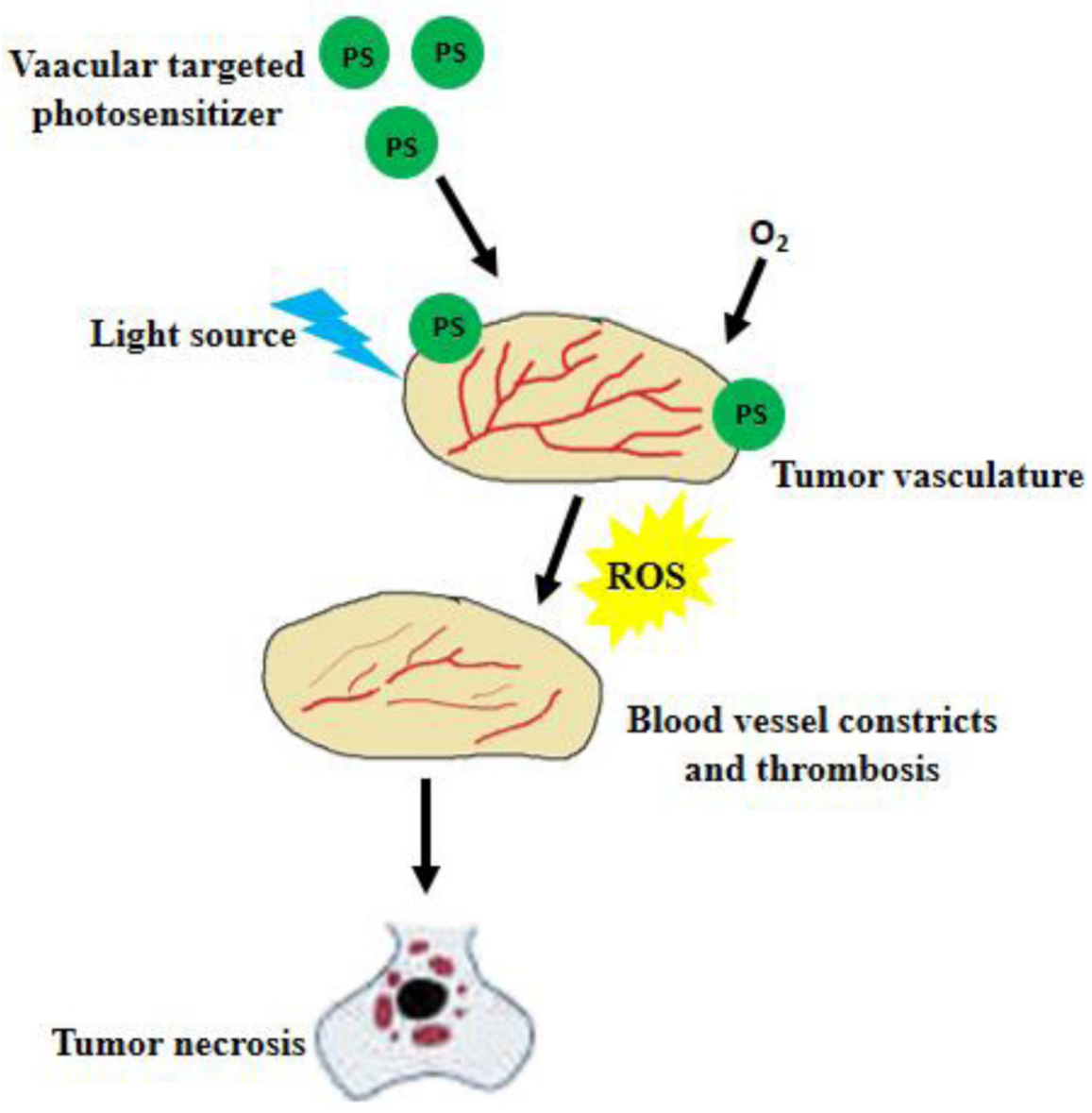

Figure 2: Mechanism of vascular targeted PDT. Vascular targeted PS accumulates in the tumor tissue. When light of suitable wavelength activates the PS, ROS is produced leading to vessel constriction, thrombosis and blood stasis; resulting in tumor necrosis. 
Table 2: PDT in clinical trials

\begin{tabular}{|l|l|l|l|}
\hline \multirow{2}{*}{ Photosensitizer } & \multicolumn{1}{c|}{ Clinical trial phase (ClinicalTrials.gov) } \\
\cline { 2 - 4 } & \multicolumn{1}{|c|}{ Phase I } & \multicolumn{1}{c|}{ Phase II } & \multicolumn{1}{c|}{ Phase III } \\
\hline $\begin{array}{l}\text { Porfimer sodium } \\
\text { (Photofrin) }\end{array}$ & Pancreatic cancer & $\begin{array}{l}\text { Human head \& neck cancer } \\
\text { Cholangiocarcinoma }\end{array}$ & $\begin{array}{l}\text { Esophageal and/or gastric } \\
\text { cardiac cancer }\end{array}$ \\
\hline $\begin{array}{l}\text { Aminolevulinic acid } \\
\text { 5-ALA) }\end{array}$ & $\begin{array}{l}\text { Early stage head \& neck tumors } \\
\text { Multple basal cell carcinomas } \\
\text { Colon cancer }\end{array}$ & $\begin{array}{l}\text { Malignant gliomas } \\
\text { Basal cell carcinoma }\end{array}$ & \\
\hline Verteporfin & Brain tumors & Age - related macular degeneration \\
\hline mTHPC (Foscan) & Non-small cell lung cancer & $\begin{array}{l}\text { Nasopharyngeal carcinoma } \\
\text { Cholangiocarcinoma }\end{array}$ & \\
\hline TOOKAD & Renal tumors & \multicolumn{3}{|l}{} \\
\hline
\end{tabular}

TOOKAD-PDT effects on human prostate cancer xenograft model in mice with small cell carcinoma of the prostate yielded a cure rate of $69 \%$ to $77 \%$. The necrotic process was by vascular damage, leading to complete destruction of the tumor, with consequent tissue remodeling 10 days post PDT. The effects on surrounding tissue were minimal due to the fragile nature of tumor vasculature and the relative resistance of normal vasculature [45]. The same group also reported rapid decline in apparent diffusion coefficient in human prostate adenocarcinoma xenografts which serves as an early response marker for successful TOOKAD-PDT [46].

WST11 (padeliporfin or TOOKAD Soluble) is a second generation photosensitizer of WST09, developed to avoid some encountered subclinical hepatotoxicity in patients with cardiovascular events [47]. WST11 eliminates the Cremophor based formulation to counteract co-solvent effects on blood pressure [48]. Several clinical studies have investigated the effects of WST11 in patients with localized PCa. It proved to be safe and efficient in canines for VTP mediated ablation of large prostatic tissue by vascular occlusion. A study involving 117 men looked at the efficacy of various combinations of WST11 $(4 \mathrm{mg} /$ $\mathrm{kg})$ and various light intensities (730 $\mathrm{nm}$ and $753 \mathrm{~nm}$ ). On day 7 post-treatment, the volume of necrosis was reduced to $76.5 \%$ with $68.4 \%$ of patients demonstrating negative biopsies by 6 months [49]. Even though focal therapies with TOOKAD-VTP are promising, they are not the standard for men with organ confined $\mathrm{PCa}$ [50]. A study reported the oncologic and functional outcomes to assess the feasibility, safety and efficacy of salvage radical prostatectomy post TOOKAD-VTP [51]. It was deemed easy for patients who received a unilateral treatment, whereas bilateral treatment induced peri - prostatic fibrosis leading to difficulties in the dissection of posterior and lateral sides of the prostate. Many groups have applied techniques to optimize and analyze VTP. The dose of light is more important for successful PDT treatment than the amount of energy delivered [52].

A phase II study with 42 men by Moore et al. [53] determined optimal drug and light dose to achieve focal ablation using WST11. Biopsy data and post treatment MRI data indicated $4 \mathrm{mg} / \mathrm{kg}$ WST11 with $200 \mathrm{~J} / \mathrm{cm}$ energy were optimal treatment conditions. Day 7 MRI results showed a negative biopsy rate of $31 \%$ in the 16 men who received $4 \mathrm{mg} / \mathrm{kg}$ WST11. In another study involving 56 patients, histopathology of prostate before and 6 months post WST11-VTP was studied [34]. Areas subjected to VTP were recognized as well demarcated hyaline fibrotic scars, with or without coagulative necrosis. Mild to moderate chronic inflammation was also observed with few atrophic benign glands, or corpora amylacea surrounded by multinuclear macrophages.

\section{MOTEXAFIN LUTETIUM}

Motexafin Lutetium (MLu) is a second generation photosensitizer with a tripyrrolic pentaaza-expanded porphyrin and an absorption wavelength of $732 \mathrm{~nm}$. MLu has reported efficacy in several murine tumor models, canine models and human clinical trials. In a study on effects of MLu and PDT delivery methods in normal canine prostate model, it was found that MLu - PDT initially caused inflammation and necrosis, followed by glandular atrophy and fibrosis [54].

A Phase I clinical trial was initiated at the University of Pennsylvania in patients with recurrent prostate carcinoma [55]. MLu was administered intravenously $(0.5-2 \mathrm{mg} / \mathrm{kg})$ at various times prior to light delivery. On measuring MLu concentrations and optical properties of human prostates, they found substantial inter and intra patient heterogeneity. Also, the mean light penetration $(732 \mathrm{~nm}$ ) of the human prostate was found to be $0.4 \mathrm{~cm}$, which is two times smaller than the canine prostate [56]. Another study by Du et al. [57] demonstrated safe and comprehensive treatment of PCa using PDT in canines and humans alike. However, a significant dose distribution variability was observed along with a rise in PSA levels post treatment. Other studies also show intra- and interpatient heterogeneity in optical properties of MLu in the prostate pre- and post- PDT [58-60].

Since PSA levels correlate to diagnosis of $\mathrm{PCa}$, PSA levels pre- and post- PDT can help measure the effectiveness of treatment. For instance, rise in PSA correlates to the invasiveness of the procedure [61]. Also, 
PSA levels are detected over a period ranging from few hours to several weeks after treatment [62-64]. MLu PDT causes a short term increase in serum PSA levels, which may be due to cellular damage, leading to release of PSA in circulation [64]. The extent of PSA reduction subsequent to its initial therapy induced spike elicits the biochemical success of PDT on prostate and may be a useful indicator of treatment efficacy [65]. Hence, the change in PSA is related to PDT dose, as well as PS concentration, in tissue [66].

As PDT requires oxygen for tumor damage, it is essential to study the hemodynamic responses, which mainly are tumor blood flow and tumor oxygen saturation. Pogue et al. hypothesized that treatment efficiency depends on tumor oxygenation during PDT, and under oxygen limiting conditions, treatment efficiency can be repealed [67]. A preliminary study on three patients found that total hemoglobin concentration (THC) and blood flow decreased during MLu - PDT along with a slight decrease tumor blood oxygen saturation [68].

\section{AMINOLEVULANIC ACID}

Aminolevulanic acid (5-ALA), a pro-drug, which is a biosynthetic precursor of the photosensitizer protoporphyrin IX [69], has led to many applications in which 5-ALA or ALA esters can be administered topically or orally (Figure 3A). PDT using 5-ALA (Figure 4) has been extensively studied in the treatment of premalignant and malignant skin tumors $[70,71]$. The introduction of topically applied 5-ALA [72] demonstrated complete response rates for non-hyperkeratotic actinic keratosis lesions exceeding 75\%. 5-ALA-PDT has also shown promising results for the treatment of superficial and nodal basal cell carcinoma [73-75] (Table 2). Unfortuately, the use of 5-ALA-PDT to treat prostate cancer is a little more mixed. Using the Dunning Rat R3327 tumor model, the intravenous application of 5-ALA with subsequent irradiation using $633 \mathrm{~nm}$ laser resulted in 97\% necrosis in one study [76] and highly variable results in another due to hypoxic conditions and poor 5-ALA distribution in tumor [77]. PDT application to normal prostate tissue in dogs resulted in small lesions suggesting weak distribution in tissue as well [78]. More in vivo studies are needed to assess 5-ALA-PDT as a clinical treatment for prostate cancer. However, 5-ALA has gained most of its recognition in the prostate field for its use in photodynamic diagnosis (PDD). Nakai et al. incubated 5-ALA with voided urine samples subsequent to prostate massage, which produced protoporphyrin IX in shed prostate cells, resulting in a $74.1 \%$ sensitivity and $70.2 \%$ specificity levels. This demonstrated higher sensitivity than both abnormal digital rectal exam and transrectal ultrasound, and more specific than PSA levels [79]. A stomach tube delivered 5-ALA orally in another study and PPD labelled cells during a radical prostatectomy resulted in $75 \%$ sensitivity and $87 \%$ specificity [80]. Early studies support potential for clinical use in diagnostics but more randomized clinical trials are needed to confirm its use.

\section{VERTEPORFIN}

Verteporfin, a benzoporphyrin derivative (Figure $3 \mathrm{~B}$ ) is commonly used as a PS for PDT to eliminate abnormal blood vessels in the eye, such as the wet form of age related macular degeneration [81]. Recently, verteporfin has gained recognition in VTP and its action is known to be mediated by the Hippo signaling pathway, which controls organ size by the regulation of cell cycle, proliferation and apoptosis [82]. The activity of Yes-associated protein (YAP) is essential in Hippo signaling, and high levels of YAP have been observed in hepatocellular carcinoma [83]. The interaction of YAP with transcription enhancers activation domain (TEAD) family, upregulates the expression of various growth factors including connective tissue growth factor

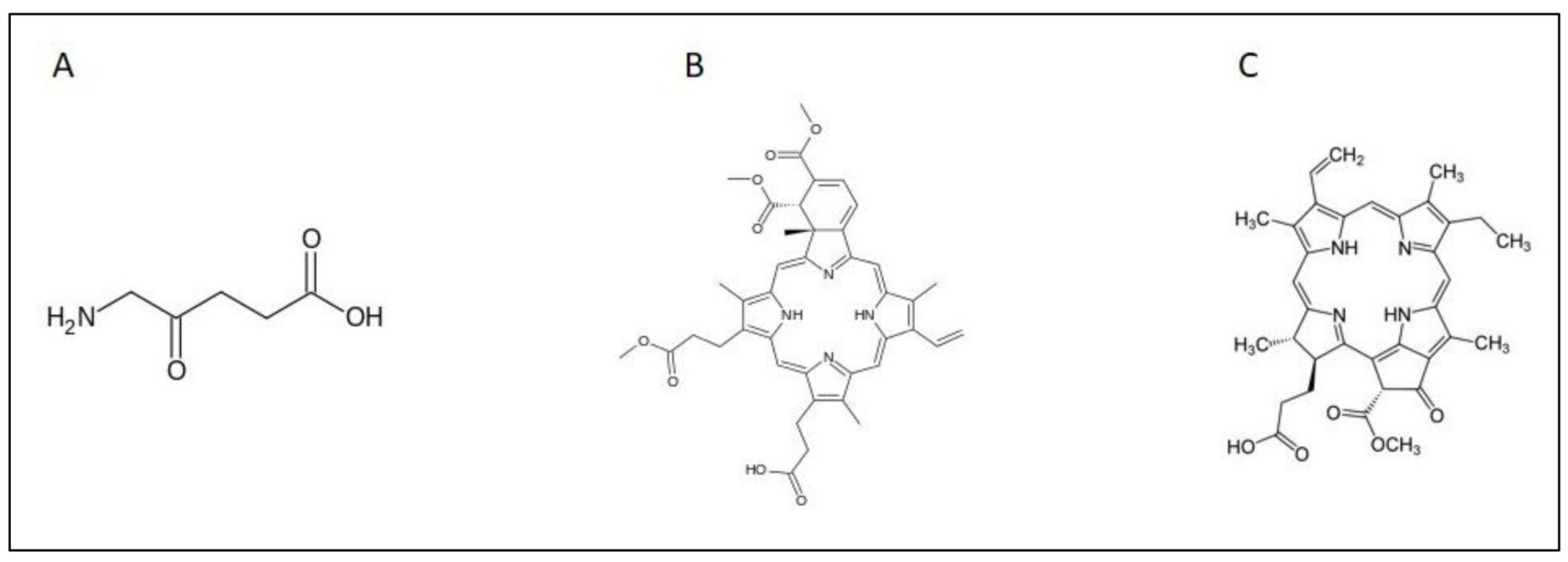

Figure 3: Chemical structures of A. 5-ALA, B. verteporfin and C. pheophorbide a 
(CTGF) and Cyr61 [84], AXL receptor tyrosine kinase [85], survivin and c-myc [86]. A study on the effects of verteporfin on retinoblastoma reported that verteporfin induces growth inhibition, apoptosis and cell cycle arrest by interfering with the YAP-TEAD growth pathway (Figure 5) [87].

Nguyen et al. [88] studied the significance of ERG in human prostate cancer and determined that ERG binds to the YAP1/TEAD region, leading to the activation of Hippo target genes. As mentioned above, verteporfin is an inhibitor of YAP-TEAD growth pathway, it has a therapeutic potential for prostate cancer. MatLyLu tumors in rat models were sensitive to verteporfin-PDT regimen inducing tumor necrosis [89]. Furthermore, VTP with verteporfin led to a dose and time-dependent increase in vascular permeability and decrease in blood perfusion in EGFP-MatLyLu prostate tumor cells [90].

\section{PHEOPHORBIDE}

Pheophorbide a ( $\mathrm{Pba})$, a breakdown product of chlorophyll $a$ (Figure 3C), can be derived from algae and higher plants [91]. Early studies comparing the photodynamic efficacy of Pba with Hematoporphyrin derivative $(\mathrm{HpD})$ in Lewis lung carcinoma in mice [92] found that $\mathrm{Pba}$ is a stronger $\mathrm{PS}$ as compared to $\mathrm{HpD}$ due to its longer wavelength of absorbance in the red region of the spectrum. Another study suggesting the therapeutic potential of Pba-PDT studied rat pituitary tumor implanted in nude mice [93]. Pba administered intravenously accumulated in the tumor, and significant reduction in tumor mass was observed upon irradiation. Pba-PDT has also been tested in vivo and in vtro in human pancreatic cancer [94, 95]. Inhibition in cell growth was observed (0.5 $\mu \mathrm{M}$ and $2 \mu \mathrm{M}$ concentrations of $\mathrm{Pba})$, along with establishing apoptosis due to DNA fragmentation as the mode of cell death. Another group studying the effects of Pba-PDT on hepatocellular carcinoma found that $\mathrm{Pba}$ accumulates in the mitochondria. Upon photoactivation, Pba induced membrane deterioration, causing release of cytochrome c into the cytoplasm, thus activating the intrinsic apoptotic pathway (Figure 7) [96, 97]. Pba-PDT has also shown promising therapeutic potential in breast cancer [98], bladder cancer [17], prostate cancer [18, 99] and esophageal cancer [100].

\section{HEMATOPORPHYRIN DERIVATIVE}

Hematoporphyrin derivative $(\mathrm{HpD})$ is a complex mixture of monomeric and aggregated porphyrins derived from hematoporphyrin. $\mathrm{HpD}$ has been used successfully for localization and photoradiation therapy of tumors [65]. HpD was first used in 1960 by Lipson and Baldes [101] in mice. The first use of HpD in humans to treat a patient with breast cancer occurred in 1966 [102] and since then, several studies on different cancers have been reported. Several groups reported the use of $\mathrm{HpD}$ in the treatment of tumors in animals [103], and in patients with bladder cancer [104], head and neck cancer [105, 106]. In 1984, Dougherty et al. [107] fractionated HpD to examine and isolate the active compounds, which were found to be multiple porphyrin ethers and esters (Figure 6). This

\section{Aminolevulinic acid}

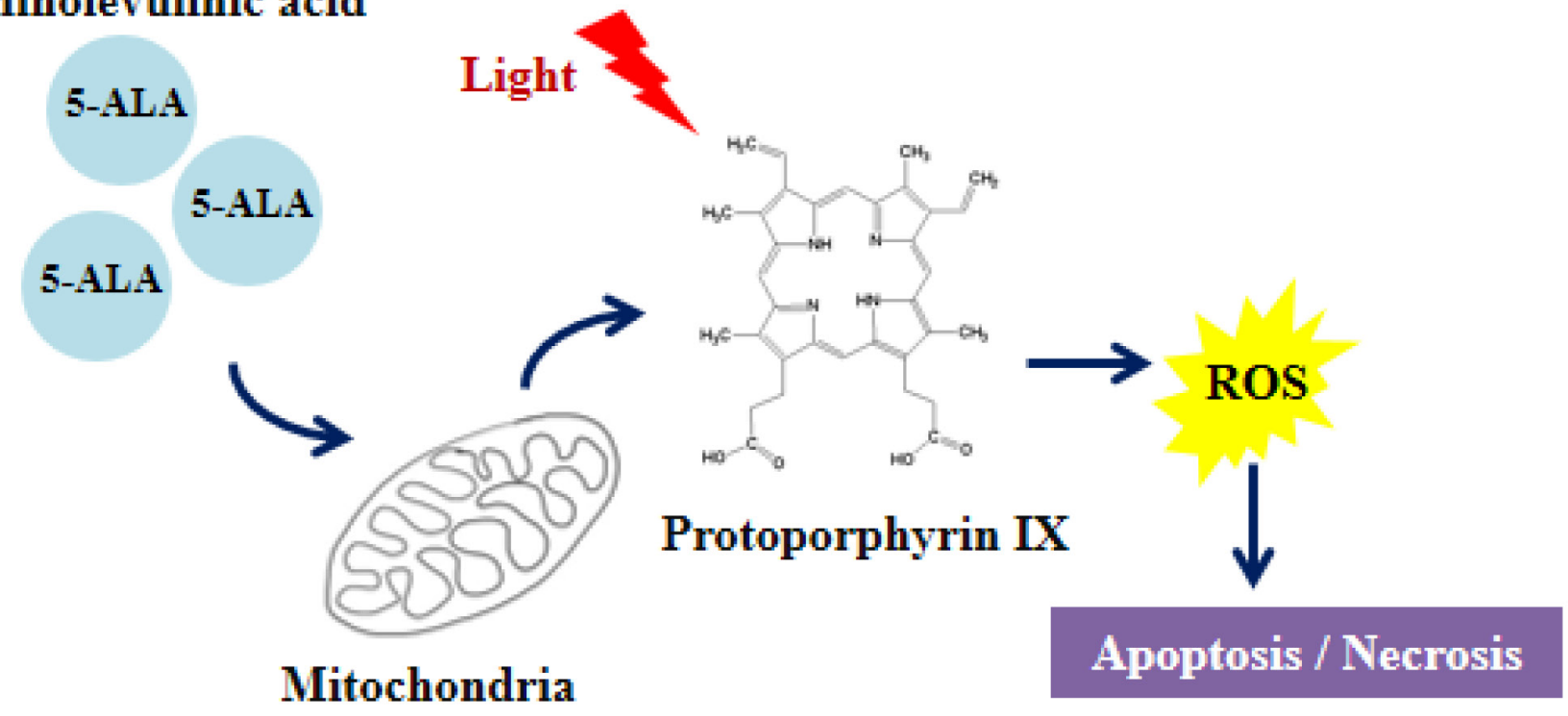

Figure 4: 5-ALA-PDT induces cell death via apoptosis/necrosis. 5-ALA accumulates in the mitochondria, and forms protoporphyrin IX using the heme synthesis pathway. Activation with light of specific wavelength causes a photodynamic reaction, producing ROS, which in turn leads to cell death. 
mixture was marketed in 1993 as Photofrin (sodium porfimer) and was approved in Canada for the treatment of early bladder cancer. The United States Food and Drug Administration approved sodium porfimer for the treatment of esophageal cancer in 1996 [108], following approval in France and The Netherlands for the treatment of advanced lung and esophageal cancer; in Germany for the treatment of early lung cancer; and Japan for the treatment of early esophageal, lung, gastric and cervical cancer [109].

\section{OTHER PHOTOSENSITIZERS}

One of the limitations of conventional PDT is poor tissue penetration of the PS due to self-aggregation rendering it unable to permeate the lipid bilayer, leading to reduced efficacy $[110,111]$. There has been a constant search for improved formulations so as to make the PS easily deliverable and highly efficacious. One such approach applies the use of nanoparticles, which can protect the PS from recognition and clearance from the biological system prior to reaching the target [112]. Upon testing polymethylmethacrylate core-shell fluorescent nanoparticles loaded with aluminium pthalocyanine (Ptl) in human prostate tumor model, Duchi et al. demonstrated that nanoparticles with Ptl significantly reduced tumor growth by $75 \%$, whereas Ptl alone could reduce tumor growth by $50 \%$ [113]. Similarly, uptake of gold nanoparticles loaded with verteporfin in HeLa was increased $(98.6 \%)$ as compared to free verteporfin $(18.86 \%)$ [114]. The use of different sizes of submicron magnetic particles in PC-3 prostate cancer cells to assess photodynamic anti-cancer activity showed successful reduction in cell viability in a size dependent manner, and the anti-cancer activity depends on the concentration inversely proportionate to particle size [115].

Along with therapeutic efficiency, PS can also be used for imaging and diagnosis of cancerous tumors. PSbased fluorescence imaging has shown promising results in the detection of ovarian cancer $[116,117]$, pancreatic cancer $[118,119]$ and lung cancer $[120,121]$.

\section{CONCLUSIONS}

PDT has potential as a focal treatment for PCa. Several clinical trials using vascular targeted photosensitizers have established it as safe, effective, feasible and repeatable. Since the first use of PDT for PCa in a clinical setting in 1990, several advances in photosensitizer design and light delivery have been achieved. Heterogeneity of response, tissue light penetration and tissue oxygenation are current limitations, which can be overcome with further studies. Potential advances in photosensitizer and light delivery, along with treatment monitoring systems, will make PDT an exciting addition to the array of treatments available for PCa in primary and post radiotherapy setting.
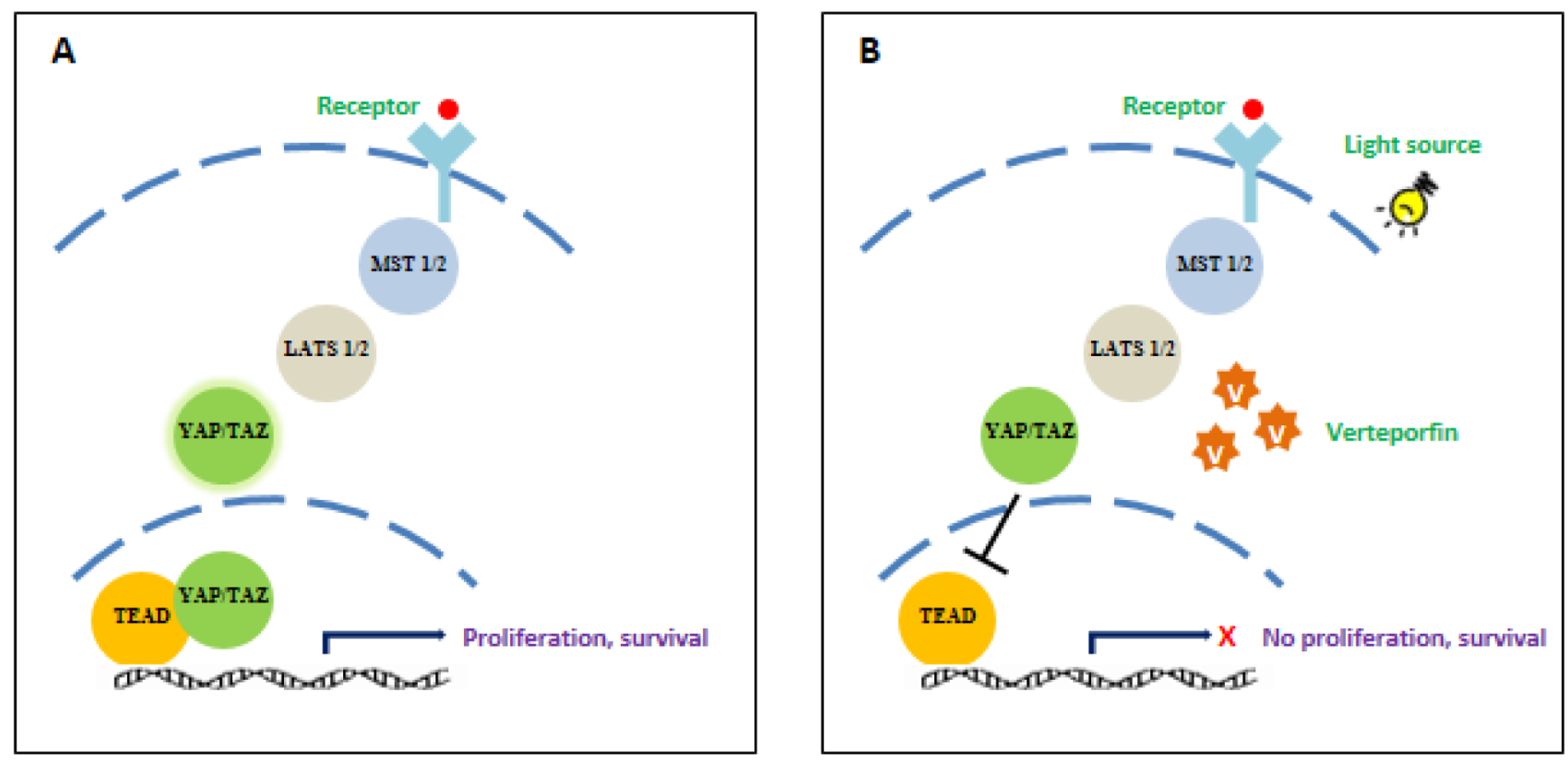

Figure 5: Verteporfin inhibits the Hippo signaling pathway, blocking cell proliferation and survival. A. Under normal conditions, growth signals activate the Hippo signaling pathway, causing the activation of YAP/TAZ complex. This complex translocates into the nucleus to form YAP/TEAD which activates several growth factors, leading to cell growth and proliferation. B. Verteporfin blocks the translocation of YAP/TAZ into the nucleus, thus inhibiting cell growth and survival. 


\section{FUTURE OF PDT IN PCa TREATMENT}

Photodynamic therapy for $\mathrm{PCa}$ can potentially be very selective and a single session treatment, as well as it can be used in primary or salvage settings. Even though photosensitivity and phototoxicity are important factors associated with PDT, researchers are attempting to establish optimum treatment parameters involving

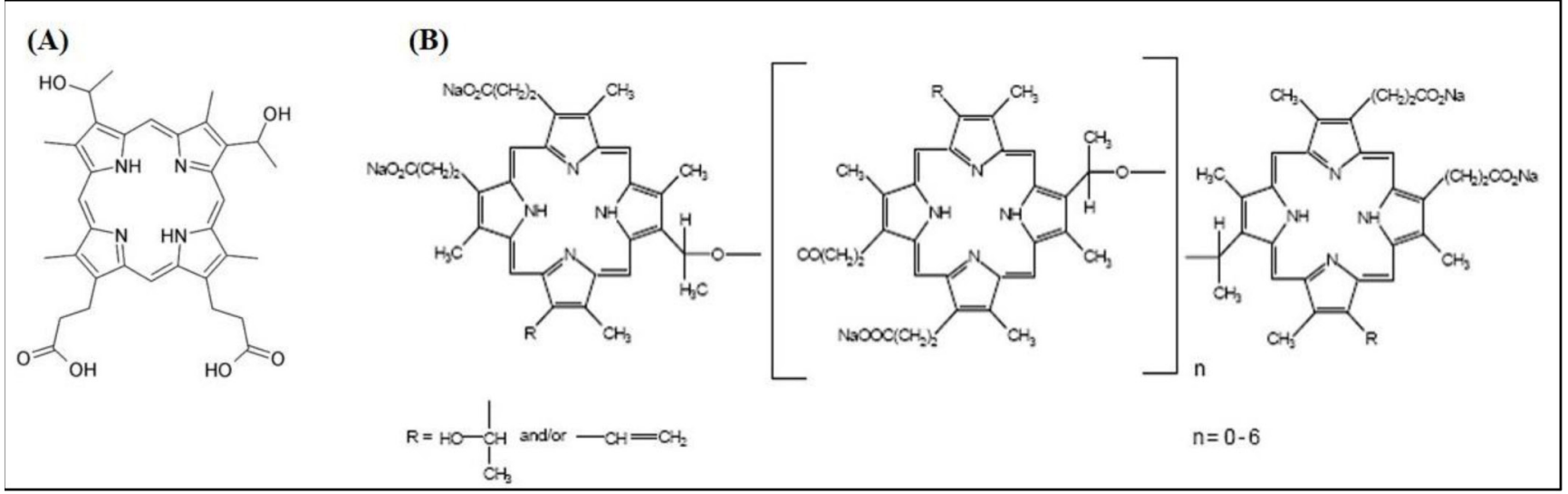

Figure 6: Structural difference between A. hematoporphyrin and B. Photofrin.

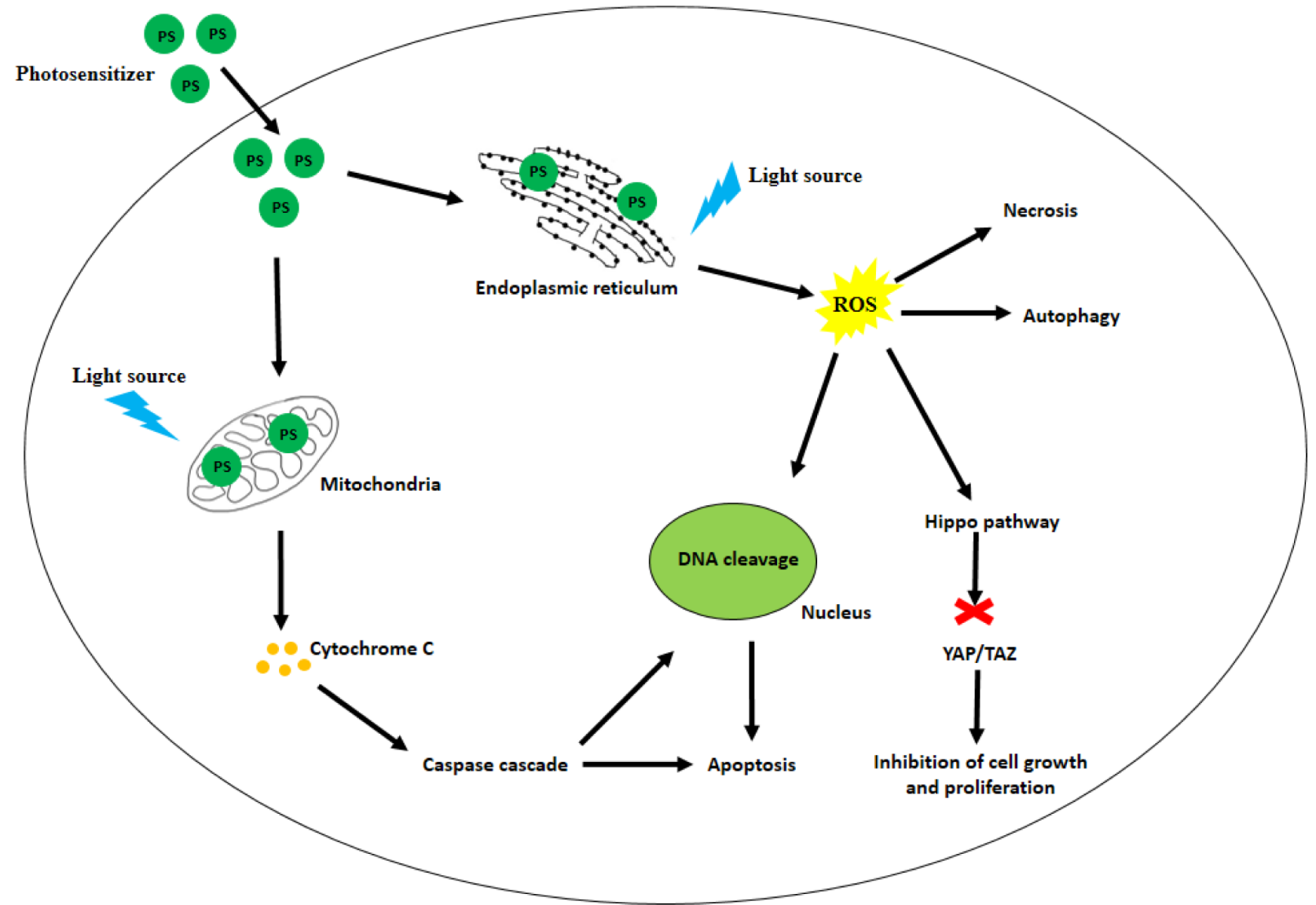

Figure 7: Various cell death pathways modulated by PDT. The PS are taken up by the malignant cells and populate in various organelles like mitochondria and the endoplasmic reticulum. Light of suitable wavelength activates the PS which in turn causes release of cytochrome $\mathrm{C}$ from the mitochondria; leading to the activation of the caspase cascade. Pro-apoptotic factors like p53 are activated, thus inducing apoptosis. Formation of ROS may also lead to necrosis or autophagy. As shown earlier, the Hippo signaling pathway can be inhibited leading to inhibition in cell growth. 
intraprostatic drug levels, light source and tissue oxygen. With the advent of new PS that specifically target cancerous tissue with minimal phototoxicity in normal tissue, the future of PDT has demonstrated promise. For PCa therapy, the light should be able to penetrate deeper under the skin through the body tissue. Hence, improvement in light delivery equipment is also being constantly improved. So far, the clinical trial data for $\mathrm{PCa}$ looks promising, and this therapy will greatly benefit men with early and advanced PCa.

\section{ACKNOWLEDGMENTS}

This study was supported by University of Illinois College of Medicine at Rockford and funding received from Brovember Inc., Rockford, IL.

\section{CONFLICTS OF INTEREST} interest.

Authors declare that they do not have conflict of

\section{REFERENCES}

1. Cancer Facts \& Figures 2016. American Cancer Society. 2016.

2. Eggener SE, Coleman JA. Focal treatment of prostate cancer with vascular-targeted photodynamic therapy. ScientificWorldJournal. 2008; 8: 963-73. doi: 10.1100/ tsw.2008.127.

3. Poissonnier L, Chapelon JY, Rouviere O, Curiel L, Bouvier R, Martin X, Dubernard JM, Gelet A. Control of prostate cancer by transrectal HIFU in 227 patients. Eur Urol. 2007; 51: 381-7. doi: 10.1016/j.eururo.2006.04.012.

4. Onik G. The male lumpectomy: rationale for a cancer targeted approach for prostate cryoablation. A review. Technol Cancer Res Treat. 2004; 3: 365-70.

5. Windahl T, Andersson SO, Lofgren L. Photodynamic therapy of localised prostatic cancer. Lancet. 1990; 336: 1139 .

6. Zaak D, Sroka R, Höppner M, Khoder W, Reich O, Tritschler S, Muschter R, Knüchel R, Hofstetter A. Photodynamic Therapy by Means of 5-ALA Induced PPIX in Human Prostate Cancer - Preliminary Results. Medical Laser Application. 2003; 18: 91-5. doi: http://dx.doi. org/10.1078/1615-1615-00092.

7. Dolmans DE, Fukumura D, Jain RK. Photodynamic therapy for cancer. Nat Rev Cancer. 2003; 3: 380-7. doi: 10.1038/ nrc1071.

8. Rutkowska-Zbik D, Witko M. Metallobacteriochlorophylls as potential dual agents for photodynamic therapy and chemotherapy. J Mol Model. 2013; 19: 4155-61. doi: 10.1007/s00894-012-1747-y.

9. Yoon I, Li JZ, Shim YK. Advance in photosensitizers and light delivery for photodynamic therapy. Clin Endosc. 2013; 46: 7-23. doi: 10.5946/ce.2013.46.1.7.

10. Wilson BC. Photodynamic therapy for cancer: principles. Can J Gastroenterol. 2002; 16: 393-6.

11. Agostinis P, Berg K, Cengel KA, Foster TH, Girotti AW, Gollnick SO, Hahn SM, Hamblin MR, Juzeniene A, Kessel D, Korbelik M, Moan J, Mroz P, et al. Photodynamic therapy of cancer: an update. CA Cancer J Clin. 2011; 61: 250-81. doi: 10.3322/caac.20114.

12. Hoi SW, Wong HM, Chan JY, Yue GG, Tse GM, Law BK, Fong WP, Fung KP. Photodynamic therapy of Pheophorbide a inhibits the proliferation of human breast tumour via both caspase-dependent and -independent apoptotic pathways in in vitro and in vivo models. Phytother Res. 2012; 26: 73442. doi: 10.1002/ptr.3607.

13. Simone CB, 2nd, Friedberg JS, Glatstein E, Stevenson JP, Sterman DH, Hahn SM, Cengel KA. Photodynamic therapy for the treatment of non-small cell lung cancer. J Thorac Dis. 2012; 4: 63-75. doi: 10.3978/j.issn.20721439.2011.11.05.

14. Chung PS, He P, Shin JI, Hwang HJ, Lee SJ, Ahn JC. Photodynamic therapy with 9-hydroxypheophorbide alpha on AMC-HN-3 human head and neck cancer cells: induction of apoptosis via photoactivation of mitochondria and endoplasmic reticulum. Cancer Biol Ther. 2009; 8: 1343-51.

15. Leggett CL, Gorospe EC, Wang KK. Endoscopic therapy for Barrett's esophagus and early esophageal adenocarcinoma. Gastroenterol Clin North Am. 2013; 42: 175-85. doi: 10.1016/j.gtc.2012.11.010.

16. Qumseya BJ, David W, Wolfsen HC. Photodynamic Therapy for Barrett's Esophagus and Esophageal Carcinoma. Clin Endosc. 2013; 46: 30-7. doi: 10.5946/ ce.2013.46.1.30.

17. Bergstrom LC, Vucenik I, Hagen IK, Chernomorsky SA, Poretz RD. In-vitro photocytotoxicity of lysosomotropic immunoliposomes containing pheophorbide a with human bladder carcinoma cells. J Photochem Photobiol B. 1994; 24: 17-23.

18. Xu DD, Lam HM, Hoeven $\mathrm{R}, \mathrm{Xu} \mathrm{CB}$, Leung AW, Cho WC. Photodynamic therapy induced cell death of hormone insensitive prostate cancer PC-3 cells with autophagic characteristics. Photodiagnosis Photodyn Ther. 2013; 10: 278-87. doi: 10.1016/j.pdpdt.2013.01.002.

19. Pegaz B, Debefve E, Ballini JP, Wagnieres G, Spaniol S, Albrecht V, Scheglmann DV, Nifantiev NE, van den Bergh H, Konan-Kouakou YN. Photothrombic activity of m-THPC-loaded liposomal formulations: pre-clinical assessment on chick chorioallantoic membrane model. Eur J Pharm Sci. 2006; 28: 134-40. doi: 10.1016/j. ejps.2006.01.008.

20. Kachatkou D, Sasnouski S, Zorin V, Zorina T, D'Hallewin MA, Guillemin F, Bezdetnaya L. Unusual photoinduced response of $\mathrm{mTHPC}$ liposomal formulation 
(Foslip). Photochem Photobiol. 2009; 85: 719-24. doi: 10.1111/j.1751-1097.2008.00466.x.

21. Petri A, Yova D, Alexandratou E, Kyriazi M, Rallis M. Comparative characterization of the cellular uptake and photodynamic efficiency of Foscan(R) and Fospeg in a human prostate cancer cell line. Photodiagnosis Photodyn Ther. 2012; 9: 344-54. doi: 10.1016/j.pdpdt.2012.03.008.

22. Silva AK, Kolosnjaj-Tabi J, Bonneau S, Marangon I, Boggetto N, Aubertin K, Clement O, Bureau MF, Luciani N, Gazeau F, Wilhelm C. Magnetic and photoresponsive theranosomes: translating cell-released vesicles into smart nanovectors for cancer therapy. ACS Nano. 2013; 7: 495466. doi: 10.1021/nn400269x.

23. Marchal S, Francois A, Dumas D, Guillemin F, Bezdetnaya L. Relationship between subcellular localisation of Foscan and caspase activation in photosensitised MCF-7 cells. Br J Cancer. 2007; 96: 944-51. doi: 10.1038/sj.bjc.6603631.

24. Yow CM, Mak NK, Leung AW, Huang Z. Induction of early apoptosis in human nasopharyngeal carcinoma cells by mTHPC-mediated photocytotoxicity. Photodiagnosis Photodyn Ther. 2009; 6: 122-7. doi: 10.1016/j. pdpdt.2009.06.003.

25. Gharehbaghi K, Kubin A, Grusch M, Gharehbaghi-Schnell E, Wierrani F, Jayaram HN, Grunberger W, Szekeres T. Photodynamic action of meta-tetrahydroxyphenylchlorin (mTHPC) on an ovarian cancer cell line. Anticancer Res. 2000; 20: 2647-52.

26. Gyenge EB, Hiestand S, Graefe S, Walt H, Maake C. Cellular and molecular effects of the liposomal mTHPC derivative Foslipos in prostate carcinoma cells in vitro. Photodiagnosis Photodyn Ther. 2011; 8: 86-96. doi: 10.1016/j.pdpdt.2011.02.001.

27. Park C, Lee I, Kang WK. Lovastatin-induced E2F-1 modulation and its effect on prostate cancer cell death. Carcinogenesis. 2001; 22: 1727-31.

28. Moore CM, Nathan TR, Lees WR, Mosse CA, Freeman A, Emberton M, Bown SG. Photodynamic therapy using meso tetra hydroxy phenyl chlorin (mTHPC) in early prostate cancer. Lasers Surg Med. 2006; 38: 356-63. doi: 10.1002/ $1 \mathrm{sm} .20275$.

29. Chang SC, Buonaccorsi G, MacRobert A, Bown SG. Interstitial and transurethral photodynamic therapy of the canine prostate using meso-tetra-(m-hydroxyphenyl) chlorin. Int J Cancer. 1996; 67: 555-62. doi: 10.1002/ (sici)1097-0215(19960807)67:4 > 555::aid-ijc15 > 3.0.co;26.

30. Selman SH, Albrecht D, Keck RW, Brennan P, Kondo S. Studies of tin ethyl etiopurpurin photodynamic therapy of the canine prostate. J Urol. 2001; 165: 1795-801.

31. Zimmermann A, Walt H, Haller U, Baas P, Klein SD. Effects of chlorin-mediated photodynamic therapy combined with fluoropyrimidines in vitro and in a patient. Cancer Chemother Pharmacol. 2003; 51: 147-54. doi: 10.1007/s00280-002-0549-9.
32. van Laar JA, Rustum YM, Ackland SP, van Groeningen CJ, Peters GJ. Comparison of 5-fluoro-2'-deoxyuridine with 5-fluorouracil and their role in the treatment of colorectal cancer. Eur J Cancer. 1998; 34: 296-306.

33. Kelleher DK, Thews O, Scherz A, Salomon Y, Vaupel P. Perfusion, oxygenation status and growth of experimental tumors upon photodynamic therapy with Pdbacteriopheophorbide. Int J Oncol. 2004; 24: 1505-11.

34. Eymerit-Morin C, Zidane M, Lebdai S, Triau S, Azzouzi AR, Rousselet MC. Histopathology of prostate tissue after vascular-targeted photodynamic therapy for localized prostate cancer. Virchows Arch. 2013; 463: 547-52. doi: 10.1007/s00428-013-1454-9.

35. Trachtenberg J, Bogaards A, Weersink RA, Haider MA, Evans A, McCluskey SA, Scherz A, Gertner MR, Yue C, Appu S, Aprikian A, Savard J, Wilson BC, et al. Vascular targeted photodynamic therapy with palladiumbacteriopheophorbide photosensitizer for recurrent prostate cancer following definitive radiation therapy: assessment of safety and treatment response. J Urol. 2007; 178: 1974-9; discussion 9. doi: 10.1016/j.juro.2007.07.036.

36. Trachtenberg J, Weersink RA, Davidson SR, Haider MA, Bogaards A, Gertner MR, Evans A, Scherz A, Savard J, Chin JL, Wilson BC, Elhilali M. Vascular-targeted photodynamic therapy (padoporfin, WST09) for recurrent prostate cancer after failure of external beam radiotherapy: a study of escalating light doses. BJU Int. 2008; 102: 55662. doi: 10.1111/j.1464-410X.2008.07753.x.

37. Weersink RA, Bogaards A, Gertner M, Davidson SR, Zhang K, Netchev G, Trachtenberg J, Wilson BC. Techniques for delivery and monitoring of TOOKAD (WST09)-mediated photodynamic therapy of the prostate: clinical experience and practicalities. J Photochem Photobiol B. 2005; 79: 21122. doi: 10.1016/j.jphotobiol.2005.01.008.

38. Weersink RA, Forbes J, Bisland S, Trachtenberg J, Elhilali M, Brun PH, Wilson BC. Assessment of cutaneous photosensitivity of TOOKAD (WST09) in preclinical animal models and in patients. Photochem Photobiol. 2005; 81: 106-13. doi: 10.1562/2004-05-31-ra-182.

39. Selman SH, Keck RW, Hampton JA. Transperineal photodynamic ablation of the canine prostate. J Urol. 1996; 156: 258-60.

40. Chen Q, Huang Z, Luck D, Beckers J, Brun PH, Wilson BC, Scherz A, Salomon Y, Hetzel FW. Preclinical studies in normal canine prostate of a novel palladiumbacteriopheophorbide (WST09) photosensitizer for photodynamic therapy of prostate cancers. Photochem Photobiol. 2002; 76: 438-45. doi: 10.1562/00318655(2002)076<0438:psincp > 2.0.co;2.

41. Huang Z, Chen Q, Dole KC, Barqawi AB, Chen YK, Blanc D, Wilson BC, Hetzel FW. The effect of Tookad-mediated photodynamic ablation of the prostate gland on adjacent tissues-in vivo study in a canine model. Photochem Photobiol Sci. 2007; 6: 1318-24. doi: 10.1039/b705984a.

42. Huang Z, Chen Q, Luck D, Beckers J, Wilson BC, Trncic 
N, Larue SM, Blanc D, Hetzel FW. Studies of a vascularacting photosensitizer, Pd-bacteriopheophorbide (Tookad), in normal canine prostate and spontaneous canine prostate cancer. Lasers Surg Med. 2005; 36: 390-7. doi: 10.1002/ 1sm.20177.

43. Huang Z, Chen Q, Trncic N, LaRue SM, Brun PH, Wilson BC, Shapiro H, Hetzel FW. Effects of Pdbacteriopheophorbide (TOOKAD)-mediated photodynamic therapy on canine prostate pretreated with ionizing radiation. Radiat Res. 2004; 161: 723-31.

44. Dole KC, Chen Q, Hetzel FW, Whalen LR, Blanc D, Huang Z. Effects of photodynamic therapy on peripheral nerve: in situ compound-action potentials study in a canine model. Photomed Laser Surg. 2005; 23: 172-6. doi: 10.1089/ pho.2005.23.172.

45. Koudinova NV, Pinthus JH, Brandis A, Brenner O, Bendel P, Ramon J, Eshhar Z, Scherz A, Salomon Y. Photodynamic therapy with Pd-Bacteriopheophorbide (TOOKAD): successful in vivo treatment of human prostatic small cell carcinoma xenografts. Int J Cancer. 2003; 104: 782-9. doi: 10.1002/ijc. 11002.

46. Plaks V, Koudinova N, Nevo U, Pinthus JH, Kanety H, Eshhar Z, Ramon J, Scherz A, Neeman M, Salomon Y. Photodynamic therapy of established prostatic adenocarcinoma with TOOKAD: a biphasic apparent diffusion coefficient change as potential early MRI response marker. Neoplasia. 2004; 6: 224-33. doi: 10.1593/neo.3352.

47. Arumainayagam N, Moore CM, Ahmed HU, Emberton M. Photodynamic therapy for focal ablation of the prostate. World J Urol. 2010; 28: 571-6. doi: 10.1007/s00345-0100554-2.

48. Brandis A, Mazor O, Neumark E, Rosenbach-Belkin V, Salomon Y, Scherz A. Novel water-soluble bacteriochlorophyll derivatives for vascular-targeted photodynamic therapy: synthesis, solubility, phototoxicity and the effect of serum proteins. Photochem Photobiol. 2005; 81: 983-93. doi: 10.1562/2004-12-01-ra-389.

49. Azzouzi AR, Barret E, Bennet J, Moore C, Taneja S, Muir G, Villers A, Coleman J, Allen C, Scherz A, Emberton M. TOOKAD $(R)$ Soluble focal therapy: pooled analysis of three phase II studies assessing the minimally invasive ablation of localized prostate cancer. World J Urol. 2015; 33: 945-53. doi: 10.1007/s00345-015-1505-8.

50. Heidenreich A, Bastian PJ, Bellmunt J, Bolla M, Joniau S, van der Kwast T, Mason M, Matveev V, Wiegel T, Zattoni F, Mottet N. EAU guidelines on prostate cancer. part 1: screening, diagnosis, and local treatment with curative intent-update 2013. Eur Urol. 2014; 65: 124-37. doi: 10.1016/j.eururo.2013.09.046.

51. Lebdai S, Villers A, Barret E, Nedelcu C, Bigot P, Azzouzi AR. Feasibility, safety, and efficacy of salvage radical prostatectomy after Tookad(R) Soluble focal treatment for localized prostate cancer. World J Urol. 2015; 33: 965-71. doi: 10.1007/s00345-015-1493-8.

52. Davidson SR, Weersink RA, Haider MA, Gertner MR,
Bogaards A, Giewercer D, Scherz A, Sherar MD, Elhilali M, Chin JL, Trachtenberg J, Wilson BC. Treatment planning and dose analysis for interstitial photodynamic therapy of prostate cancer. Phys Med Biol. 2009; 54: 2293 313. doi: $10.1088 / 0031-9155 / 54 / 8 / 003$.

53. Moore CM, Azzouzi AR, Barret E, Villers A, Muir GH, Barber NJ, Bott S, Trachtenberg J, Arumainayagam N, Gaillac B, Allen C, Schertz A, Emberton M. Determination of optimal drug dose and light dose index to achieve minimally invasive focal ablation of localised prostate cancer using WST11-vascular-targeted photodynamic (VTP) therapy. BJU Int. 2015; 116: 888-96. doi: 10.1111/ bju.12816.

54. Hsi RA, Kapatkin A, Strandberg J, Zhu T, Vulcan T, Solonenko M, Rodriguez C, Chang J, Saunders M, Mason N, Hahn S. Photodynamic therapy in the canine prostate using motexafin lutetium. Clin Cancer Res. 2001; 7: 651-60.

55. Zhu TC, Dimofte A, Finlay JC, Stripp D, Busch T, Miles J, Whittington R, Malkowicz SB, Tochner Z, Glatstein E, Hahn SM. Optical properties of human prostate at $732 \mathrm{~nm}$ measured in mediated photodynamic therapy. Photochem Photobiol. 2005; 81: 96-105. doi: 10.1562/2004-06-25-ra216.

56. Zhu TC, Hahn SM, Kapatkin AS, Dimofte A, Rodriguez $\mathrm{CE}$, Vulcan TG, Glatstein E, Hsi RA. In vivo optical properties of normal canine prostate at $732 \mathrm{~nm}$ using motexafin lutetium-mediated photodynamic therapy. Photochem Photobiol. 2003; 77: 81-8.

57. Du KL, Mick R, Busch TM, Zhu TC, Finlay JC, Yu G, Yodh AG, Malkowicz SB, Smith D, Whittington R, Stripp D, Hahn SM. Preliminary results of interstitial motexafin lutetium-mediated PDT for prostate cancer. Lasers Surg Med. 2006; 38: 427-34. doi: 10.1002/1sm.20341.

58. Finlay JC, Zhu TC, Dimofte A, Stripp D, Malkowicz SB, Busch TM, Hahn SM. Interstitial fluorescence spectroscopy in the human prostate during motexafin lutetium-mediated photodynamic therapy. Photochem Photobiol. 2006; 82: 1270-8. doi: 10.1562/2005-10-04-ra-711.

59. Verigos K, Stripp DC, Mick R, Zhu TC, Whittington R, Smith D, Dimofte A, Finlay J, Busch TM, Tochner ZA, Malkowicz S, Glatstein E, Hahn SM. Updated results of a phase I trial of motexafin lutetium-mediated interstitial photodynamic therapy in patients with locally recurrent prostate cancer. J Environ Pathol Toxicol Oncol. 2006; 25: 373-87.

60. Zhu TC, Finlay JC, Hahn SM. Determination of the distribution of light, optical properties, drug concentration, and tissue oxygenation in-vivo in human prostate during motexafin lutetium-mediated photodynamic therapy. J Photochem Photobiol B. 2005; 79: 231-41. doi: 10.1016/j. jphotobiol.2004.09.013.

61. Bunting PS. A guide to the interpretation of serum prostate specific antigen levels. Clin Biochem. 1995; 28: 221-41.

62. Long R, Giri S, Diver S, Duddy L, McKeown D, Moran $\mathrm{K}$. Effect of prostate manipulation on the serum levels of 
complexed prostate-specific antigen and total prostatespecific antigen. Int $\mathrm{J}$ Urol. 2006; 13: 947-50. doi: 10.1111/j.1442-2042.2006.01445.x.

63. Collins GN, Martin PJ, Wynn-Davies A, Brooman PJ, O'Reilly PH. The effect of digital rectal examination, flexible cystoscopy and prostatic biopsy on free and total prostate specific antigen, and the free-to-total prostate specific antigen ratio in clinical practice. J Urol. 1997; 157: 1744-7.

64. Leibovici D, Zisman A, Lindner A, Stav K, Siegel YI. PSA elevation during prostate cryosurgery and subsequent decline. Urol Oncol. 2005; 23: 8-11. doi: 10.1016/j. urolonc.2004.06.005.

65. Kupeli S, Soygur T, Yilmaz E, Aytac S. Effect of transurethral electrovaporization of the prostate on serum prostate specific antigen concentration. BJU Int. 1999; 83: 783-5.

66. Patel H, Mick R, Finlay J, Zhu TC, Rickter E, Cengel KA, Malkowicz SB, Hahn SM, Busch TM. Motexafin lutetiumphotodynamic therapy of prostate cancer: short- and longterm effects on prostate-specific antigen. Clin Cancer Res. 2008; 14: 4869-76. doi: 10.1158/1078-0432.ccr-08-0317.

67. Pogue BW, O'Hara JA, Demidenko E, Wilmot CM, Goodwin IA, Chen B, Swartz HM, Hasan T. Photodynamic therapy with verteporfin in the radiation-induced fibrosarcoma-1 tumor causes enhanced radiation sensitivity. Cancer Res. 2003; 63: 1025-33.

68. Yu G, Durduran T, Zhou C, Zhu TC, Finlay JC, Busch TM, Malkowicz SB, Hahn SM, Yodh AG. Real-time in situ monitoring of human prostate photodynamic therapy with diffuse light. Photochem Photobiol. 2006; 82: 1279-84. doi: 10.1562/2005-10-19-ra-721.

69. De Rosa FS, Bentley MV. Photodynamic therapy of skin cancers: sensitizers, clinical studies and future directives. Pharm Res. 2000; 17: 1447-55.

70. Braathen LR, Szeimies RM, Basset-Seguin N, Bissonnette R, Foley P, Pariser D, Roelandts R, Wennberg AM, Morton CA, International Society for Photodynamic Therapy in Dermatology. Guidelines on the use of photodynamic therapy for nonmelanoma skin cancer: an international consensus. International Society for Photodynamic Therapy in Dermatology, 2005. J Am Acad Dermatol. 2007; 56: 125-43. doi: 10.1016/j.jaad.2006.06.006.

71. Nestor MS, Gold MH, Kauvar AN, Taub AF, Geronemus RG, Ritvo EC, Goldman MP, Gilbert DJ, Richey DF, Alster TS, Anderson RR, Bank DE, Carruthers A, et al. The use of photodynamic therapy in dermatology: results of a consensus conference. J Drugs Dermatol. 2006; 5: 140-54.

72. Kennedy JC, Pottier RH, Pross DC. Photodynamic therapy with endogenous protoporphyrin IX: basic principles and present clinical experience. J Photochem Photobiol B. 1990; 6: 143-8,

73. Taub AF. Photodynamic therapy: other uses. Dermatol Clin. 2007; 25: 101-9. doi: 10.1016/j.det.2006.09.007.
74. Wolf P, Rieger E, Kerl H. Topical photodynamic therapy with endogenous porphyrins after application of 5-aminolevulinic acid. An alternative treatment modality for solar keratoses, superficial squamous cell carcinomas, and basal cell carcinomas? J Am Acad Dermatol. 1993; 28: 17-21.

75. Cairnduff F, Stringer MR, Hudson EJ, Ash DV, Brown SB. Superficial photodynamic therapy with topical 5-aminolaevulinic acid for superficial primary and secondary skin cancer. Br J Cancer. 1994; 69: 605-8.

76. Zaak D, Sroka R, Stocker S, Bise K, Lein M, Hoppner M, Frimberger D, Schneede P, Reich O, Kriegmair M, Knuchel R, Baumgartner R, Hofstetter A. Photodynamic therapy of prostate cancer by means of 5-aminolevulinic acid-induced protoporphyrin IX - in vivo experiments on the dunning rat tumor model. Urol Int. 2004; 72: 196-202. doi: $10.1159 / 000077114$.

77. Bozzini G, Colin P, Betrouni N, Maurage CA, Leroy X, Simonin S, Martin-Schmitt C, Villers A, Mordon S. Efficiency of 5-ALA mediated photodynamic therapy on hypoxic prostate cancer: a preclinical study on the Dunning R3327-AT2 rat tumor model. Photodiagnosis Photodyn Ther. 2013; 10: 296-303. doi: 10.1016/j.pdpdt.2013.01.003.

78. Chang SC, Buonaccorsi GA, MacRobert AJ, Bown SG. Interstitial photodynamic therapy in the canine prostate with disulfonated aluminum phthalocyanine and 5-aminolevulinic acid-induced protoporphyrin IX. Prostate. 1997; 32: 89-98.

79. Nakai Y, Anai S, Kuwada M, Miyake M, Chihara Y, Tanaka N, Hirayama A, Yoshida K, Hirao Y, Fujimoto K. Photodynamic diagnosis of shed prostate cancer cells in voided urine treated with 5-aminolevulinic acid. BMC Urol. 2014; 14: 59. doi: 10.1186/1471-2490-14-59.

80. Fukuhara H, Inoue K, Kurabayashi A, Furihata M, Shuin T. Performance of 5-aminolevulinic-acid-based photodynamic diagnosis for radical prostatectomy. BMC Urol. 2015; 15: 78. doi: 10.1186/s12894-015-0073-y.

81. Scott LJ, Goa KL. Verteporfin. Drugs Aging. 2000; 16: 13946; discussion 47-8.

82. Huang J, Wu S, Barrera J, Matthews K, Pan D. The Hippo signaling pathway coordinately regulates cell proliferation and apoptosis by inactivating Yorkie, the Drosophila Homolog of YAP. Cell. 2005; 122: 421-34. doi: 10.1016/j. cell.2005.06.007.

83. Xu MZ, Yao TJ, Lee NP, Ng IO, Chan YT, Zender L, Lowe SW, Poon RT, Luk JM. Yes-associated protein is an independent prognostic marker in hepatocellular carcinoma. Cancer. 2009; 115: 4576-85. doi: 10.1002/cncr.24495.

84. Zhao B, Ye X, Yu J, Li L, Li W, Li S, Yu J, Lin JD, Wang CY, Chinnaiyan AM, Lai ZC, Guan KL. TEAD mediates YAP-dependent gene induction and growth control. Genes Dev. 2008; 22: 1962-71. doi: 10.1101/gad.1664408.

85. Xu MZ, Chan SW, Liu AM, Wong KF, Fan ST, Chen J, Poon RT, Zender L, Lowe SW, Hong W, Luk JM. AXL 
receptor kinase is a mediator of YAP-dependent oncogenic functions in hepatocellular carcinoma. Oncogene. 2011; 30: 1229-40. doi: 10.1038/onc.2010.504.

86. Lu L, Li Y, Kim SM, Bossuyt W, Liu P, Qiu Q, Wang Y, Halder G, Finegold MJ, Lee JS, Johnson RL. Hippo signaling is a potent in vivo growth and tumor suppressor pathway in the mammalian liver. Proc Natl Acad Sci U S A. 2010; 107: 1437-42. doi: 10.1073/pnas.0911427107.

87. Brodowska K, Al-Moujahed A, Marmalidou A, Meyer Zu Horste M, Cichy J, Miller JW, Gragoudas E, Vavvas DG. The clinically used photosensitizer Verteporfin (VP) inhibits YAP-TEAD and human retinoblastoma cell growth in vitro without light activation. Exp Eye Res. 2014; 124: 67-73. doi: 10.1016/j.exer.2014.04.011.

88. Nguyen LT, Tretiakova MS, Silvis MR, Lucas J, Klezovitch O, Coleman I, Bolouri H, Kutyavin VI, Morrissey C, True LD, Nelson PS, Vasioukhin V. ERG Activates the YAP1 Transcriptional Program and Induces the Development of Age-Related Prostate Tumors. Cancer Cell. 2015; 27: 797 808. doi: 10.1016/j.ccell.2015.05.005.

89. Chen B, Pogue BW, Zhou X, O'Hara JA, Solban N, Demidenko E, Hoopes PJ, Hasan T. Effect of tumor host microenvironment on photodynamic therapy in a rat prostate tumor model. Clin Cancer Res. 2005; 11: 720-7.

90. Chen B, Crane C, He C, Gondek D, Agharkar P, Savellano MD, Hoopes PJ, Pogue BW. Disparity between prostate tumor interior versus peripheral vasculature in response to verteporfin-mediated vascular-targeting therapy. Int $\mathrm{J}$ Cancer. 2008; 123: 695-701. doi: 10.1002/ijc.23538.

91. Takamiya KI, Tsuchiya T, Ohta H. Degradation pathway(s) of chlorophyll: what has gene cloning revealed? Trends Plant Sci. 2000; 5: 426-31.

92. Roeder B, Naether D, Lewald T, Braune M, Nowak C, Freyer W. Photophysical properties and photodynamic activity in vivo of some tetrapyrroles. Biophys Chem. 1990; 35: 303-12.

93. Yano T, Uozumi T, Kawamoto K, Mukada K, Onda J, Ito A, Fujimoto N. Photodynamic therapy for rat pituitary tumor in vitro and in vivo using pheophorbide-a and white light. Lasers Surg Med. 1991; 11: 174-82.

94. Sohn TA, Yeo CJ, Cameron JL, Koniaris L, Kaushal S, Abrams RA, Sauter PK, Coleman J, Hruban RH, Lillemoe KD. Resected adenocarcinoma of the pancreas- 616 patients: results, outcomes, and prognostic indicators. J Gastrointest Surg. 2000; 4: 567-79.

95. Hajri A, Coffy S, Vallat F, Evrard S, Marescaux J, Aprahamian M. Human pancreatic carcinoma cells are sensitive to photodynamic therapy in vitro and in vivo. Br J Surg. 1999; 86: 899-906. doi: 10.1046/j.13652168.1999.01132.x.

96. Chan JY, Tang PM, Hon PM, Au SW, Tsui SK, Waye MM, Kong SK, Mak TC, Fung KP. Pheophorbide a, a major antitumor component purified from Scutellaria barbata, induces apoptosis in human hepatocellular carcinoma cells.
Planta Med. 2006; 72: 28-33. doi: 10.1055/s-2005-873149.

97. Tang PM, Liu XZ, Zhang DM, Fong WP, Fung KP. Pheophorbide a based photodynamic therapy induces apoptosis via mitochondrial-mediated pathway in human uterine carcinosarcoma. Cancer Biol Ther. 2009; 8: 533-9. doi: 10.4161/cbt.8.6.7694.

98. Bui-Xuan NH, Tang PM, Wong CK, Fung KP. Photoactivated pheophorbide-a, an active component of Scutellaria barbata, enhances apoptosis via the suppression of ERK-mediated autophagy in the estrogen receptornegative human breast adenocarcinoma cells MDAMB-231. J Ethnopharmacol. 2010; 131: 95-103. doi: 10.1016/j.jep.2010.06.007.

99. Della Pietra E, Simonella F, Bonavida B, Xodo LE, Rapozzi V. Repeated sub-optimal photodynamic treatments with pheophorbide a induce an epithelial mesenchymal transition in prostate cancer cells via nitric oxide. Nitric Oxide. 2015; 45: 43-53. doi: 10.1016/j.niox.2015.02.005.

100. Wu D, Liu Z, Fu Y, Zhang Y, Tang N, Wang Q, Tao L. Efficacy of 2-(1-hexyloxyethyl)-2-devinyl pyropheophorbide-a in photodynamic therapy of human esophageal squamous cancer cells. Oncol Lett. 2013; 6: 1111-9. doi: 10.3892/ol.2013.1493.

101. Lipson RL, Baldes EJ. The photodynamic properties of a particular hematoporphyrin derivative. Arch Dermatol. 1960; 82: 508-16.

102. Lipson RL, Baldes EJ, Gray MJ. Hematoporphyrin derivative for detection and management of cancer. Cancer. 1967; 20: 2255-7.

103. Diamond I, Granelli SG, McDonagh AF, Nielsen S, Wilson CB, Jaenicke R. Photodynamic therapy of malignant tumours. Lancet. 1972; 2: 1175-7.

104. Kelly JF, Snell ME. Hematoporphyrin derivative: a possible aid in the diagnosis and therapy of carcinoma of the bladder. J Urol. 1976; 115: 150-1.

105. Wile AG, Dahlman A, Burns RG, Berns MW. Laser photoradiation therapy of cancer following hematoporphyrin sensitization. Lasers Surg Med. 1982; 2: 163-8.

106. McCaughan JS, Jr., Guy JT, Hawley P, Hicks W, Inglis W, Laufman L, May E, Nims TA, Sherman R. Hematoporphyrin-derivative and photoradiation therapy of malignant tumors. Lasers Surg Med. 1983; 3: 199-209.

107. Dougherty TJ, Potter WR, Weishaupt KR. The structure of the active component of hematoporphyrin derivative. Prog Clin Biol Res. 1984; 170: 301-14.

108. McCaughan JS, Jr., Ellison EC, Guy JT, Hicks WJ, Jones JJ, Laufman LR, May E, Nims TA, Spiridonidis $\mathrm{CH}$, Williams TE. Photodynamic therapy for esophageal malignancy: a prospective twelve-year study. Ann Thorac Surg. 1996; 62: 1005-9; discussion 9-10. doi: 10.1016/00034975(96)00563-2.

109. McCaughan JS, Jr. Photodynamic therapy: a review. Drugs Aging. 1999; 15: 49-68. 
110. Allen CM, Sharman WM,Van Lier JE. Current status of phthalocyanines in the photodynamic therapy of cancer. Journal of Porphyrins and Phthalocyanines. 2001; 05: 1619. doi: 10.1002/jpp.324.

111. Qualls MM, Thompson DH. Chloroaluminum phthalocyanine tetrasulfonate delivered via acid-labile diplasmenylcholine-folate liposomes: Intracellular localization and synergistic phototoxicity. International Journal of Cancer. 2001; 93: 384-92. doi: 10.1002/ijc.1339.

112. Hong EJ, Choi DG, Shim MS. Targeted and effective photodynamic therapy for cancer using functionalized nanomaterials. Acta Pharm Sin B. 2016; 6: 297-307. doi: 10.1016/j.apsb.2016.01.007.

113. Duchi S, Ramos-Romero S, Dozza B, Guerra-Rebollo M, Cattini L, Ballestri M, Dambruoso P, Guerrini A, Sotgiu G, Varchi G, Lucarelli E, Blanco J. Development of near-infrared photoactivable phthalocyanine-loaded nanoparticles to kill tumor cells: An improved tool for photodynamic therapy of solid cancers. Nanomedicine. 2016; 12: 1885-97. doi: 10.1016/j.nano.2016.04.014.

114. Zhao L, Kim T-H, Kim H-W, Ahn J-C, Kim SY. Enhanced cellular uptake and phototoxicity of Verteporfin-conjugated gold nanoparticles as theranostic nanocarriers for targeted photodynamic therapy and imaging of cancers. Materials Science and Engineering: C. 2016; 67: 611-22. doi: http:// dx.doi.org/10.1016/j.msec.2016.05.047.

115. Choi KH, Nam KC, Malkinski L, Choi EH, Jung JS, Park BJ. Size-Dependent Photodynamic Anticancer Activity of Biocompatible Multifunctional Magnetic Submicron Particles in Prostate Cancer Cells. Molecules. 2016; 21. doi: 10.3390/molecules21091187.

116. Ludicke F, Gabrecht T, Lange N, Wagnieres G, van den
Bergh H, Berclaz L, Major AL. Photodynamic diagnosis of ovarian cancer using hexaminolaevulinate: a preclinical study. Br J Cancer. 2003; 88: 1780-4.

117. Zhong W, Celli JP, Rizvi I, Mai Z, Spring BQ, Yun $\mathrm{SH}$, Hasan $\mathrm{T}$. In vivo high-resolution fluorescence microendoscopy for ovarian cancer detection and treatment monitoring. Br J Cancer. 2009; 101: 201522. doi: http://www.nature.com/bjc/journal/v101/n12/ suppinfo/6605436s1.html.

118. Yurt Lambrecht F, Ocakoglu K, Er O, Ince M, Gunduz $\mathrm{C}$, Kayabasi C. Nuclear imaging potential and in vitro photodynamic activity of symmetrical and asymmetrical zinc phthalocyanines. J Labelled Comp Radiopharm. 2016; 59: 221-7. doi: 10.1002/jlcr.3395.

119. Shishkova N, Kuznetsova O, Berezov T. Photodynamic Therapy in Gastroenterology. Journal of Gastrointestinal Cancer. 2013; 44: 251-9. doi: 10.1007/s12029-013-9496-4.

120. Shao J, Dai Y, Zhao W, Xie J, Xue J, Ye J, Jia L. Intracellular distribution and mechanisms of actions of photosensitizer Zinc(II)-phthalocyanine solubilized in Cremophor EL against human hepatocellular carcinoma HepG2 cells. Cancer Letters. 330: 49-56. doi: 10.1016/j. canlet.2012.11.017.

121. Maduray K, Odhav B. The in vitro photodynamic effect of laser activated gallium, indium and iron phthalocyanine chlorides on human lung adenocarcinoma cells. Journal of Photochemistry and Photobiology B: Biology. 2013; 128: 58-63. doi: http://dx.doi.org/10.1016/j. jphotobiol.2013.08.003. 